\title{
Digital Fuzziness or das Ungefähre The Semiotics of Cultural Practices in the Digital Realm
}

\author{
J. Krasni \\ UNIVERSITY OF NIŠ
}

Abstract. This paper reflects on the fuzzy relation between representational practices in the digital realm, the meaning which emerges out of them and their role in digital discourses. The media practices acquired by the media users impact significantly on interpersonal online discourses. The users are, however, only vaguely aware of the semiotic systems and the culture(s) they (re)create. Various forms of approximate knowledge can be identified when analysing the recurring patterns od practices in different contexts. They show how content related meaning making processes intertwine with both the media format and its distributional infrastructures.

The theoretical concept of approximate knowledge (das Ungefähre) will be exemplified with three formats of online multimodal discourses. The digital fuzzy practices encompass the relation between the distributed media content and user generated content (UGC) which share the same means of production, similar dissemination infrastructure and aesthetic standards. This relation represents the basic thread of the discursive mass production of sense in the online realm, which is based on approximate knowledge and fuzzy discursive production by the users. This content in its flow represents series of actions within the discourse, and it cannot be analysed outside of the technical infrastructure which it needs in order to exist.

Krasni J. Digital Fuzziness or das Ungefähre. The Semiotics of Cultural Practices in the Digital Realm // Критика и семиотика. 2018. № 2. С. 250-270.

ISSN 2307-1737. Критика и семиотика. 2018. № 2

(C) J. Krasni, 2018 
Key terms: multimodal discourse, online media apparatus, semiotics of digital realms, approximate knowledge, cultural practices.

DOI 10.25205/2307-1737-2018-2-250-270

Contact Information: Jan Krasni, PhD, Assistant Professor, University of Niš, Ćirila i Metodija 2 (18000 Niš, Serbia, jan.krasni@filfak.ni.ac.rs)

\section{Introduction}

Approximate knowledge allows one to laugh at the joke without really knowing what it is about, without knowing its immediate context or reference, and without belonging to the same milieu as the joke teller. It is this a phenomenon which explains the logic behind Zizek's anecdotal claim that 'he can criticise the movie before watching it'. ${ }^{1}$ In order to show how it works in the online environment, we will reflect on some examples of user generated content (UGC) from different realms of our digital life. The term UGC in the narrow sense of the word denotes only what 'private' users create. Since the content in the social media like Facebook, Instagram and Twitter is often posted by media professionals - who post also on news portals - it is hard to speak about only one kind of 'user' and his/her typical content. For these reasons, we find that the distribution and communication networks differ only in the degree of the content's formal integration into the infrastructure, the autonomy of the creators and the quality of multimodal expression. Multimodal language is itself a fuzzy set of changeable semiotic resources and rules characteristic for the digital online communication among all participants - users - in the public sphere.

Firstly, we will consider an example of a user generated unit of the newsfeed on the privately-owned meme website 9gag - which has many elements of a social network. This newsfeed is mostly edited by the community through the system of points, in spite of the partial censorship in regard to the explicit content by an algorithm and a team. Secondly, we will examine the newsfeed on the mobile version of the German privately-owned portal Spiegel Online. This website has an online editing team which works autonomously from the offline editing board. Finally, we will consider the thematic webpage of the TV news show Panorama which belongs to the German public broadcasting enterprise ARD/NDR. This portal also has an editing team dealing with the online presence and dissemination of the excerpts from the show or any other supporting material.

In the theoretical part, the method of multimodal meaning making i.e. multimodal discourse analysis (MDA, Kress and van Leeuwen 2006), the discourse polyphony approach i.e. theory of the discourse polyphony (TDP, Angermuller

\footnotetext{
${ }^{1}$ As stated in the interview for Cahiers du Cinema. See the anecdotic representation: https://www.lrb.co.uk/blog/2010/04/09/fatema-ahmed/stalinist-self-criticism/, retrieved on 15.2.2018. Or see the interview where the statement is more ambiguous: Delorme and Tessé 2010 .
} 
2007), the theory of key visual (KV) as a unit of collective mediated memory and of multimodal narrative (Kramer and Ludes 2010), all of which were already combined (Krasni 2017b), will be broadened with the 'fuzzy approach' to the online media. The discourses in the digital environment show specificities which make the communicative act between the user and the media (as a plurality of heterogeneous actors) significantly different than in other semiotic environments such as print media, radio or TV. The proper tool to analyse online communication - and/or any other kind of distribution of large amounts of digital content - needs to tackle several levels of discourse. In this case, on the level of a single unit, the analysis involves the multimodal structure of the user generated (or manipulated) formats; on the contextual level, the discursive polyphony allows the interference of implicit and explicit discursive instances; on the level of the digital flow, its construction defines the mediated memory. The borders between these levels of discourse are of course fuzzy, but they are still recognisable as separate entities.

\section{Theoretical Considerations}

In regard to the theoretical framework, the analysis of a digital discourse demands basic knowledge about - and sometimes simultaneous analysis of - the online media apparatus/dispositive. Whereas the field of discourse analysis is largely defined by the specific disciplines (linguistics, sociology, media studies) which often only remotely call upon Foucault's framework, the notion of apparatus is much closer to his original definition: "a thoroughly heterogeneous ensemble, consisting of discourses, institutions, architectural planning, regulatory decisions, laws, administrative measures, scientific statements, philosophical, moral and philanthropic proportions - in short, the said as much as the unsaid. [...] The dispositive itself is the network that can be established between these elements." (Foucault 1980: 194). Agamben's notion of this relatively broad concept is given in his work on apparatus, which he broadens with the etymological development of the term rooted in philosophy and theology (Agamben 2009). By doing it, Agamben puts the economic and technical dimension of the apparatus in the foreground. However complex (or in Marx' sense full of contradictions) the apparatus network may be, it will not become like that or change unless the interests of respective relevant social actors materialized in specific discourses - are fulfilled. ${ }^{2}$

Therefore, when dealing with a specific discourse in the digital realm, and especially in the context of approximate knowledge, the structure and the economic base of the analysed media need to be taken into account. The sociotechnological network between the user, the technology itself, the content to which the user is exposed, the media infrastructure through which the user inter-

\footnotetext{
${ }^{2}$ Actor-network-theory also pursues this line of argumentation. The difference between the proposed methodology lies in the focus on the representational discourse.
} 
acts with the media, with the content and the discourse itself are all elements of the apparatus defining the discourse. In other words, the use of the wearables or other devices and the corresponding software all have certain semiotic relevance which is to be taken into account. The structure of the media market based on contracts between media outlets and agencies which provide them with latest news in form of texts as well as with video and photographic material (Thussu 2007, Boyd-Barret 2010) are all significant parts of the narrative building mechanism, since these can be / are used to create a specific agenda (Thussu 2003: 121).

The format of the media and UGC which will be analysed in this paper is very compact and resembles the front page of a newspaper. These elements are multimodal - they are constituted by a short (lede or introduction) text and an appropriate picture and are divided from the rest of the page through some other visual element (e.g. a line). Such units in the news portals are called newsbites (Knox 2007), but the same format is characteristic for the UGC in various social networks including the portals such as 9gag. This kind of units represent an example of the autonomous intertext since its use is to take the reader to the designated text; at the same time, they exist simultaneously as a 'sharable' entity. Therefore, they possess a narrative property within a larger structure composed of similar units (Knox 2009). The higher level of the multimodal composition has its own rules of meaning making - which correspond largely to montage, the fuzzy grammar of multimodal text format (Krasni 2015). These micro elements - in the case of their repetition throughout various sources i.e. media infrastructures - have a chance to become units of collective memory, depending on their foregrounding.

\section{Methodological Considerations}

The digital discourse demands methodological pluralism, which sees the way the online media work as one of many factors in a semiotic process. Our methodology comprises multimodal analysis (MDA) and the theory of the discourse polyphony (TDP) (explained in more detail elsewhere: Krasni 2015, Krasni 2017b). Concerning the structure of the media format, social semiotics offer some postulates within the MDA (Kress and van Leeuwen 2006) broadened in the field of online discourse in more detail (Machin 2004, Machin and van Leeuwen 2007). The semiotic modes within the multimodal composition in the digital environment are structured according to specific rules of design, which in time become the general rules of communication in the online realm. Their structure shows the pragmatic as well as the discursive value.

The discourse includes contesting subject positions which are always in some way interacting through and within the representations. The subjects are not always represented, but they, or rather their voices, are always (implicitly) present through the explicit display of their counterparts. The notion of intersubjectivity constitutes the fundament of the theory of discourse polyphony (TDP) 
which recognises and reconstructs the 'voices' of the 'other side' and tries to describe the orchestration of the analysed text (Angermüller 2014). The notions of TDP related to the problem of approximate knowledge are the preconception (Pecheux 1982, Angermüller 2007) and the complementary notion of presupposition (Ducrot 1984). In the context of online media, the preconception should be understood as the pre-knowledge based on media experience, whereas the presupposition denotes the expectation horizons of the user. In other words, this method allows us to determine different layers of subjectivity in a given representation such as explicit and implicit actorship. This is highly relevant in regard to (often untrackable) origin of the material, represented action used within and action of representation of the multimodal composition (Krasni 2017b), as well as for the position proportions in the discourse, i.e. the dominance of the discursive position in the given representation.

The last element of the analysis in this context is vital for understanding the practice of mediated memory. The Key Visuals serve as a unit of multimodal narratives existing mostly as an intertext itself. They stand for the representation which defines the memory of the online media user community just as they stood for the memory of the audience in the former generations of the screen media (Ludes 2001). Crystallizing the media event and the corresponding sets of values, they are disseminated as a part of any given multimodal format, quotable throughout the media, and underlie the process of constant remediation (Kramer and Ludes 2010). The KVs are phenomena connected to the consequence of approximate knowledge since they are a part of an already formed and stable discourse emerging from the content flow. The flow is what makes the knowledge approximate, fuzzy/gradual and (directly and contextually) relevant to the thematic field (Krasni 2017a: 87-90). The media flow itself forms a threedimensional spiral; the remembrance occurs through the slightly different iterations of every turn the flow may take (Kramer 2004: 19, Giesecke 2002: 121).

\section{Approximate knowledge}

Approximate knowledge can be described as a broad awareness (of a specific entity such as a situation, event, person etc.) based on the traces of both media material and corresponding media practices. The German word for this phenomenon, das Ungefähre, is related to the manner (style, standard, trend or even a fashion) of displaying content that one is aware of thanks either to the media competence actively acquired by learning or by the media inherent intuition passively developed by being exposed to them (Krasni 2017a). The attribute approximate does not relate to the respective meaning of every small element used for the construction of a multimodal text format as these stay clear and unambiguous (both for the producer or the recipient) in the given communicative act. It is related to the potential discursive standpoints and positions emerging from the sum of the material discourse traces and to the recontextuali- 
zation practice of specific generic content. Approximate knowledge emerges from the specific practice of using a given content in a specific way, being at the same time relatively independent of the content or the practice itself. The definition of knowledge from the epistemological perspective is given in the formula: ' $\mathrm{x}$ knows that $\mathrm{p}$ ', whereas $\mathrm{x}=$ person, $\mathrm{p}=$ content (Schnädelbach 2002: 31-37). The approximate knowledge anchored in the extensive practice of online media demands an adaptation of the mentioned formula: $n$ knows that $r$, whereas $n$ is the abstraction of the media user or a member of a society exposed to the media flow, and $r$ is the representation. The representation itself should be defined as $\mathrm{r}=\mathrm{p} / \mathrm{c}$, whereas the $\mathrm{p}=$ content, and $\mathrm{c}=\mathrm{communication}$ infrastructure which defines the very semiotic processes of the online realm (Krasni 2017a: 131-132).

When talking about approximate knowledge, one should take into account the content which makes impact i.e. motivates the reading, initiates memorising and reproduction through attracting readers' attention. Collective memory in the digital realm - as in all systems for preservation of both knowledge and collectivity - is defined as a cultural praxis based mostly on repetition and attention (Assmann 2006). Its units, defined as crystallization points across the media, are the Key Visuals (Krasni 2014). They are repetitively recycled throughout the discourse because of their mnemonic properties. The practice of discursive recontextualization (Bernstein 1990), while stabilising the collective knowledge, relates to the original meaning of the element using different forms of reference such as quotation, rebuttal or even parody in a media specific manner. While forming the approximate knowledge, the recontextualized element takes part simultaneously in other discourses, other bodies of knowledge, serving as their fuzzy reference. The body of knowledge, the rationale or the dominant discursive position - sharp and clear only in the case of a strong discursive interest or conflict of two or more opposed sides - is embedded in the discursive field. The discursive field is marked through the (recontextualized) elements of approximate knowledge. Whereas the body of knowledge is a result of the discursive process and is usually analysed a posteriori, the approximate knowledge is unclear and blurred and can be analysed in the course of its making.

\section{Digital Fuzziness}

The term approximate knowledge refers to the process in which the horizon of expectation is created, with discursive positions not yet completely formed and the taboos not completely defined, yet the roles already ascribed to the social actors. The material traces of this process can be recognised as the flow of heterogeneous media formats (remotely) related to a respective discourse topic. The mediated memory exists parallel to the bodies of knowledge and is related mostly to the particular events or actors of the mainstream discourse. The difference between the approximate knowledge and the mediated memory is fluid as they condition each other: the KV unit can serve to illustrate a particular event, 
whereas the knowledge is needed in order to embed the unit in the larger construction. The mediated knowledge is more complex than the memory and consists of sets of communicated values, events, actors and relations, all of which are learned and involuntarily acquired through the constant practice of and participation in the media culture (as a user/audience).

The concept of fuzziness is widespread across many disciplines: from philosophy, through literary studies, the mathematics all the way up to the informational sciences. Its main thread lies in the overcoming the idea of oppositions (i.e. true/false, paradigmatic/syntactic) and concentrating on the notion of graduality. This means that every phenomenon is just a state within a continuum of qualities. In the context of media, the ambiguity is the given feature of discursive elements as well as human competence to reattribute them (Herman 2009: 100-102). On the other hand, this also means that all the content within human representational systems is a mere construction, wherein meaning is based on the qualities selected by either the author or the user (recipient). ${ }^{3}$ The idea behind the concept of digital fuzziness could be seen as radical relativism which (de-)justifies any discursive position. This seems to be a perfect methodological framework for the post-truth era in the digital realm since it describes the communicative phenomena in the online communities.

In order to define the narrative, many seek for a practical definition rooted in the media material. The definition becomes itself a fuzzy set, which allows "variable degrees of membership, but centred on prototypical cases that everybody recognizes as stories" (Ryan 2007: 28). This kind of 'fuzzy' definition around the catalogue of the eight rules in four dimensions of the human representational system and the further eight conditions (Ryan 2007: 29-31) ${ }^{4}$ - provides an interesting construction from the narratologist's point of view but does not help with the fact that the narrative and its units can themselves be fuzzy. Just as the boundary between the text types and media formats gets fuzzier, the use of the units and the strategical narrative thinking becomes more complex: the logic of the discourse itself stops being purely syntactic on lower levels of its existence.

The fuzzy concept draws loosely on the problem of comics - on the granularity of the units of meaning. It introduces a different understanding of graduality which can be best explained as the composition where the meaning of the whole supersedes the sum of its single units without making them lose their particular meaning. The single picture, multimodal unit of the comic takes part in the macro meaning making process if preceded and succeeded by others, in

\footnotetext{
${ }^{3}$ One can argue that the vagueness is far more precise description than the clearness since the latter one is based on the simplification.

${ }^{4}$ These categories are not directly relevant for this article, but they serve as an illustration for gradual understanding of a communication phenomenon. The eight conditions show that the following dimensions of the narrative are present in the respective (media) construction: spatial, temporal, mental, formal and pragmatic.
} 
the specific comic-context (Baetens and Surdiacourt 2011). At the same time, any (or at least some) of those visual units are able to be autonomous - in which case their meaning is slightly different. The concept of fuzziness deals with the very border between the single, the immediate (context based), and the whole hence the meaning depends on the understanding (awareness or intuition) of graduality. Even though this idea draws on the concept of the frame of a single comic picture or of a strip, the frame itself has a semiotic function in all media formats. Its fundamental role of delimitating different 'wholes' and at the same time bringing them together is the breaking point in the digital culture and the important part of the 'shareable' elements of the digital discourse.

In the digital culture, the fuzzy concept follows not only the narrative, but also the logic of the database and the algorithm aesthetics (Manovich 2002: 199-201). However, the question about the relation between the narrative and the database has to be raised differently than in the beginning of 2000s when this was a rather new phenomenon and had to fit in the syntagmatic and paradigmatic relations and the order of the traditional culture (ibid. 203-205). The many borders between many wholes emphasise the radical particularisation of the digital content units and show that some help is needed in order to keep an overview of the narrative. This help comes in the form of algorithms which govern the many databases (of these units) by creating (their own?) narratives. The algorithm, of course, does not work completely automatically and autonomously; human editing is always present at some level. The logic behind the online media is to combine the one of the database and the one of the narrative, the one of the user swarm and the one of the algorithm.

This hybrid is far more implicit since the units keep their pure narrative mechanisms e.g. answering journalistic questions or representing an actor of a story. On other levels of the whole, these mechanisms differ. If compared with the media format of comics (or a graphic novel), the online media will reveal that they also function on several levels simultaneously and are partly autonomous. In addition to the traditional (comic or newspaper) page display, the digital text format also displays a dynamic temporal dimension and a possibility of content linking. In other words, its borders are structured differently than in any other offline media format. They are more porous and let the wholes (multimodal units) be integrated into larger structures making them often less recognisable - but not less significant for the discourse. This fundamental property of graduality internalised by the multimodal units in the global online communication culture is the main cause of the fuzziness of the algorithmically disseminated knowledge (and their transformability from a small unit to a completely different structure of a discursive whole).

\section{Analysis}

Three forms of multimodal communication will be discussed in the context of approximate knowledge: the memes, the mobile version of a German online 
news magazine and the news portal of the TV show Panorama concentrated on the one topic only. These examples show differences in both the realisations and the structures of knowledge approximation.

Example 1: Memes
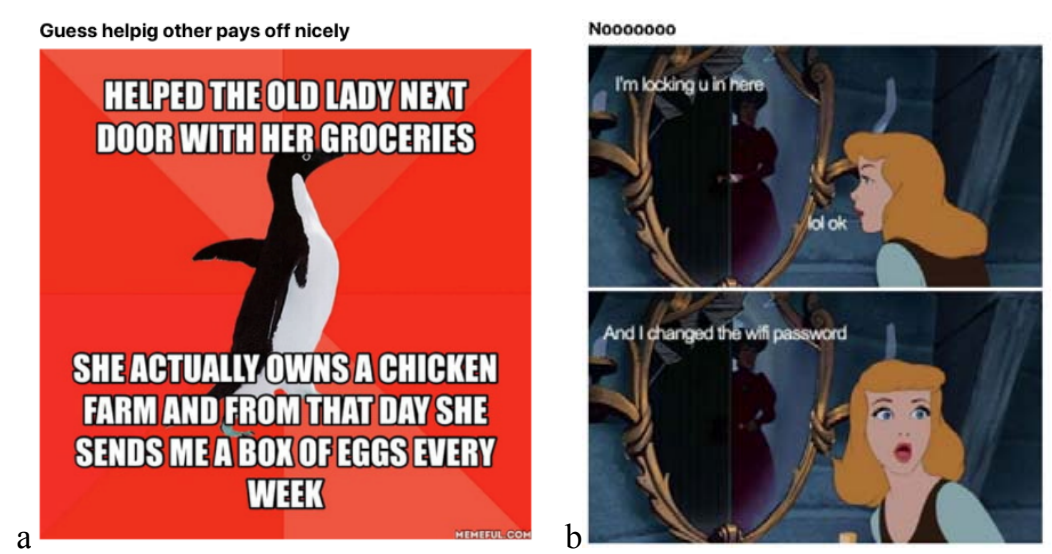

FB is only one letter away from $\mathrm{FBI}$, let that sink in... When you post a funny joke to the Messenger group chat
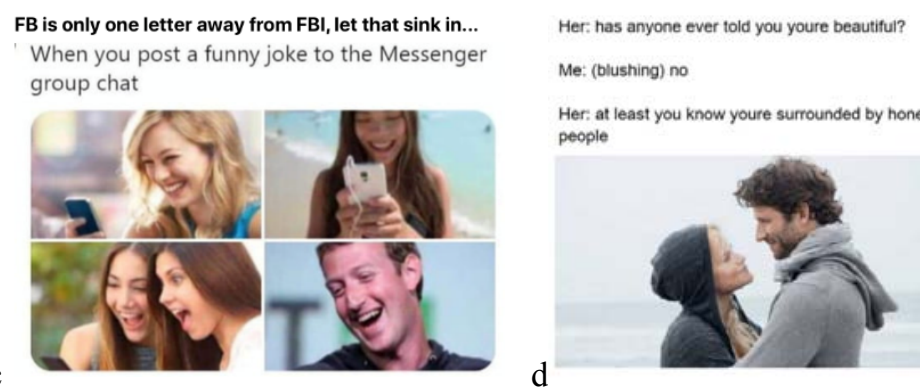

Me: (blushing) no

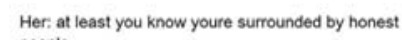

$$
\text { people }
$$

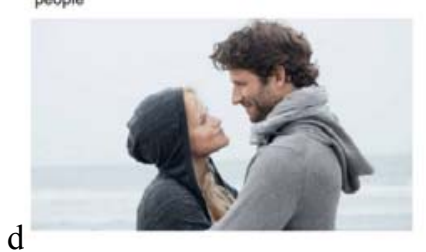

I made dis
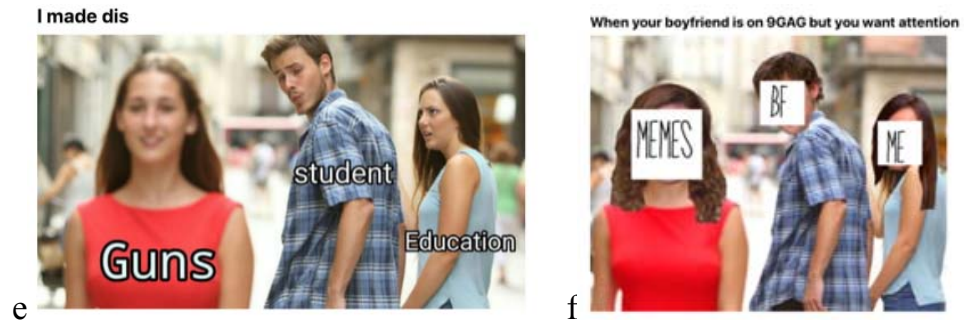

Figure 1: examples of different sorts of memes. Except for b, all the others are based on stock photographs or their derivatives. The principle of recontextualization is visible in e and f. Various anonymous authors, source: 9gag.com, 2018 
The culture of memes is deeply rooted in the economy of online news agencies. With the emergence of the digital technology and online infrastructure, large companies started acquiring rights to digital visual material in order to sell licences for its commercial usage. This business model continues a much older tradition - the so called stock photography has existed since the $19^{\text {th }}$ century. It emerged just after the new technology of photography gained wide acceptance and soon grew into an industry dominated by several corporations. The companies with the largest databases of digital stock photography today are Corbis and Getty images (Schleichkorn 2007: 350-353). The most privately owned mainstream media - not only news portals, but also businesses like online marketing - use the services of these databanks because they are cheap, the imagery is strongly standardised and large online archives exists, easily searchable as the images are provided with proper indexing, i.e., description tags. This standardisation went so far that specific abstract terms (e.g. representations of happiness, sadness or even love) in the mainstream media are defined through the technical properties of the mostly generic pictures, which largely defines the montage language of the global media (Machin 2004, Machin and van Leeuwen: 2007). The generation which grew up with this visual tradition (the so called digital natives) started to experiment with travesty-through-recontextualization of these properties, which later evolved into a culture of its own - the culture of memes. Found mostly on websites like 9gag, 8chan, Memegenerator etc., the memes use a variety of topics from popular culture, covering all possible domains of life and taking many different forms (Shifman 2014). Memes are a short media format, often assembled using the generic/stock visual content and a personalised linguistic comment (in different semiotic modes). These small units basically resemble the newspaper lead or the newsbite in many ways: not only do they contain condensed information, but they also serve as an intertext, usually connecting the multimodal unit with the discussion about some element they are travestying. The reason users understand memes lies in their common experience of the media context. ${ }^{5}$ The memes function, however, by not delivering the intuitively expected relation between the generic picture and the text. Their use shows the deep productive intertwining between the online- and media economic systems with the everyday culture. The semiotic mechanism behind the memes is mostly the previously mentioned principle of recontextualization. As described by Bernstein (2000), recontextualization stands for the adaptation of knowledge to different socially organised and institutional discursive contexts e.g. its transfer from a scientific institution (research institute) to institutions of

\footnotetext{
${ }^{5}$ One could argue that a person who never used internet would not understand the meme. However, this standpoint can't be defended since a meme is a broad concept which includes also elements of offline humor.
} 
education (such as a school, college or a university); however, this can also be applied to discourses of politics and almost any other field of life. On a different level, a phenomenon such as online meme serves as an example of how recontextualization of economic discursive practices impacts on the mainstream culture.

The above examples (fig. 1) show different kinds of memes and different ways of their work, by no means representing a complete list. Any attempt at a categorisation of specific types of memes or graphic materials used to produce them would not make sense since the number of pictures and their possible variations would result in more exceptions than rules. However, some common basic rules can be recognized - the reasons why we understand the phenomenon can be described. Firstly, the knowledge these memes rely on is the one of the media world (opposite of Machin and van Leeuwen, 2007: 157). This allows us to recognise the properties of visual elements. In other words, we recognise the properties of a Disney cartoon (fig. $1 \mathrm{~b}$ ), the concept of a couple in love (fig. 1 d), a jealousy scene (fig. 1 e and f), a dramatic conflict symbolized by the red colour (fig. $1 \mathrm{a}$, e and f), the counterintuitive (confusing and therefore awkward!) combination of the colour and the animal (fig. 1 a), the display of happy people and the similar production of Zuckerberg (fig. $1 \mathrm{c}$ ) and other generic and yet typical visual representations of abstract concepts realised in different contexts. Secondly, the text applied in different layers of linguistic content is relatively short and stands for the new context in this (personal, humorous) iteration. The given set of visual properties is therefore in these examples detached from the author's contribution. The 'aura' of originality, the authenticity of the composition or any connection with the author are irrelevant since the number of iteration decides about the reach - or in the terms of memes, the number of reposts - which is the imperative. The famous Eco's instances within the division of intentio auctoris, operis and lectoris are now all to be understood as collectives because both the author and the work are to be understood only in plural. This also means that the concept of user generated content (UGN) becomes problematic. Its ready-made nature (present also in other social media formats) shows the high level of standardisation when it comes to creativity even in the relatively non-standardised field of humour. Consequently, the polyphony of this media format is a given fact - the social actors of the representation are all involved in the interaction with the actors of distribution. The users (producers and recipients-as-potential-reproducers) are all aware that the content and the infrastructure, the discourse and the apparatus are indivisibly and consciously mixed up. This awareness stands for the common, approximate media knowledge, das Ungefähre which enables the existence of this community. 
Example 2: Context of Mobile News

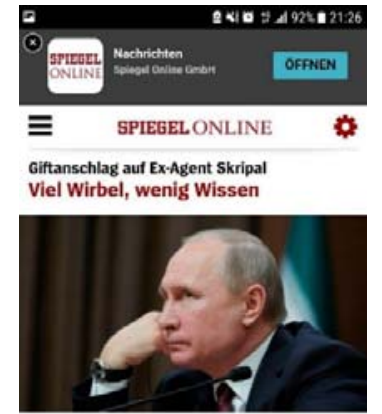

Vor einem Monat wurde der ExAdent Skripal vergitet-London wirt Moskou vor, verantwortich au sein. Die Belege sind dunn. Beide Lander geraten immer heftiger aneinander. Was wir Christina Hebel, Moskau mehr..

Fall Skripal und Umgang mit Russtand: cDUVize Laschet rweifelt am Vorgehen des Westens

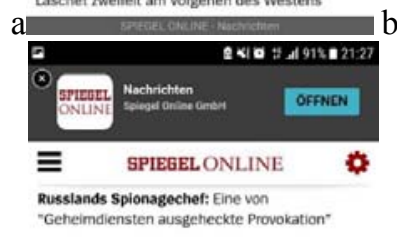

Zabridge-Analytica-skandal Zahl der Geschädigten deutlich höher als bislang bekannt

Der Facetoook Skandal ist deutich yober atu bistang angenommen. Daten von bis zu 87 Mallionen 50 Millionen betroffenen Nutzern ausgetanger meht.

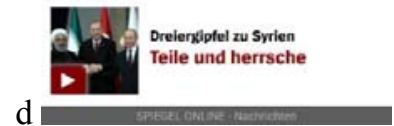

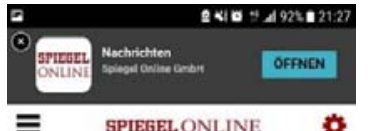

$\equiv \quad$ SPIEgELONLINE

Fall Skripal: Brntisches AulBenministerium soll Tweet ober angeblichen Gift teweis geloscht haber

Vor der OPCW: London lehnt gemeinsame Untersuchung im Fall Skripal ab

Vorwürte im Fall Skripal Russland fordert Sitzung des Uno-sicherteitsrats Russlind will den Streit mit GroBbritannien iber die Vergitung des ExAgenten Sergel Skripal im betischen Vorwörte hat Moskau eine Sonderstzung beantragt. mehr... Russlands Spionarechef: Eine von
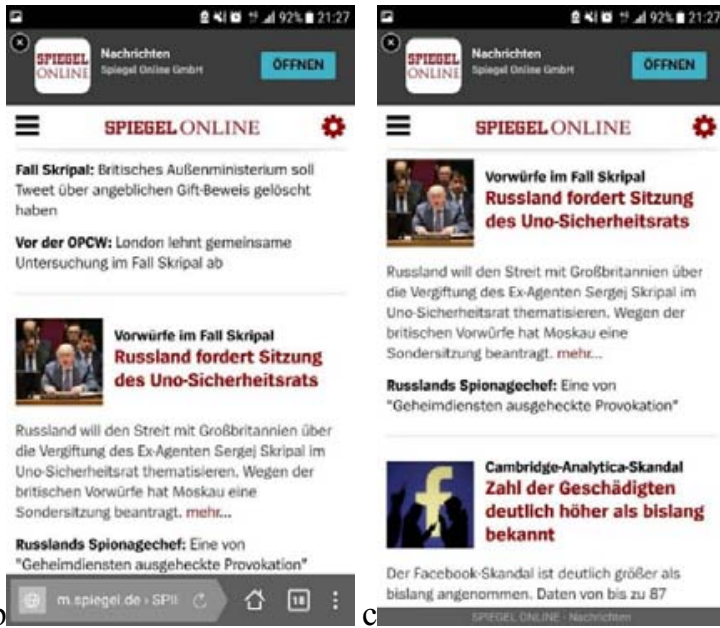

三 SPIEGELONLINE क

[9. 5 vorwùrfe im Fall skripal if iity Russland fordert Sitzung A. 2 des Uno-Sicherheitsrats Russtand will den Stret mit GroBbrtannien uber

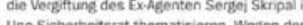
Witischen Worworde hat Moskew eine Sondersitung beantragt. mehic. Russlands Spionagechet: Eine von "Gecheimdiensten ausechechte Provokation"

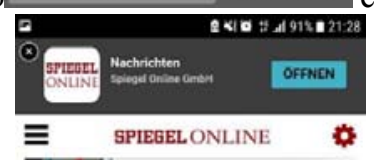

$\equiv$ SPIEGELONLINE
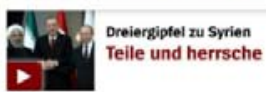

Russland, han und de Tirkei entsonteiden ober Syriens Zukunt. Bei einem Treffen der. Stastschefs Putin, Rohani und Erdogan in Ankas Bing es jetzt vor allem um die strategischen Interessen der drei Lander, Von Dominik Peters und Maximilan Popp mehr.

rotostrecke: Sechs Augen Gespràch in Ankara

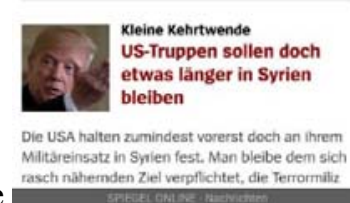

Figure 2: Stills from the SPON mobile website with the ad for the SPON mobile app. Recontextualisation of the neighbouring newsbites in the discursive flow in spite of the thematic division. Translation of the titles (bold and red text): a) Poison Attack on the Former Agent Scripal; The Scripal case and How to Handle Russia; b) The Scripal Case; Before the OCPW; Objections in the Scripal Case - Russia Demands a Meeting of UN Security Council; Russia's Chief of Espionage; c) The Scandal of Cambridge Analytica Number of Victims Significantly Higher Than Previously Known; d) Trilateral Summit on Syria - Divide and Conquer; e) Foto Series; A Small U-Turn - US Troops Should Still Stay a Bit Longer in Syria 
The online version of the weekly magazine Der Spiegel, Spiegel Online (SPON) is one of the most popular news portals in Germany. ${ }^{6}$ The freely accessible content segment is based on the agency news coverage, whereas more sophisticated content, such as long reads and interviews produced by the Spiegel (senior) journalists demands subscription. The editorial team of the SPON is divided from the editors of the 'offline' magazine and has relative freedom in adjusting the content and the overall design for the online audience. The following examples represent the front pages of SPON as they are grouped in the newsfeed for the small screen of a mobile device. They represent the screen while scrolling the news on this portal. Many different news webpages are optimised for mobile applications and there are important differences between the mobile view of the webpage, the computer view and the content available through the app of a given media outlet.

The mobile webpage displays the content in a more restricted manner compared with the larger computer screen. In other words, when on the frontpage, one can only see the content on the vertical axis of a specific given newsbite and only rarely the content of the horizontal axis. The gaze of the user is therefore controlled in so far as only the movement up/down or into/through the intertextual unit is possible. However, the very nature of the newsbites as intertextual units demands further thematic classification. This is possible only on the vertical axis which is at the same time the chronological one. In this way, two principles - the thematic and the chronological - are combined. Further semiotic vehicles are introduced to prevent the two from interfering with each other. The thematic clusters belong to one larger newsbite complex, whereas the different topics are held divided in separate complexes. The two principles still collide since the thematic one interferes with the chronological - the neighbouring units become considered as at least relatable to some extent.

The snapshots show us the view which the user would be exposed to if scrolling on the frontpage of the SPON at a specific moment in time (Fig. 2). The semiotic blocks based on the vicinity are at the same time examples of recontextualization through content. The gaze as a semiotic mechanism is controlled through a significantly reduced trajectory and the viewing space which allows to see only clustered elements. The semiotic device of vicinity, on the other hand, is clustering the neighboured elements. The mechanism within the newsbite shows that the visual content represents the affirmative comment of the linguistic part - being the illustration of the actors or the situation in question - which functions different than in the case of memes. In spite of that, it is the visual element that represents the core of the new thematic whole, whereas the typographic element articulates the meaning. The bold title - or its part with the colon - represents a subsection within the thematic whole. This is what the

\footnotetext{
${ }^{6}$ The news from www.spiegel.de are retrieved from its mobile version on 6.4.2018.
} 
user intuitively understands thanks to their linguistic and media competence. At the same time, it also creates a certain confusion because not all the newsbites have a visual core and the linguistic elements create interference by using similar wording. The neighbouring effect shows that the meaning construction and its hierarchies are the part of the discursive flow which is not necessarily detached from the chronological one. In other words, the constructions of the chronological order and the discursive flow are hardly separable.

We can say that the four narratives (across the fig. 2) are connected with each other in various ways. The connecting elements are the words repeated in the first three newsbites, but also the context construed between the thematic blocks. In other words, the first two newsbites are related to Russia, the third one deals with Facebook - as we know because of the supposed Russian meddling in the US elections - and the fourth one connects the meeting on Syria and Trump's opinion on US troops in Syria. The first newsbite - as the opening one - has the largest picture which defines the rest of the flow. On the formal level, this newsbite represents the latest important news; implicitly, at least when it comes to the mobile view of this website, it defines the reading of both the information and the discourse flow on the vertical axis.

The MDA recognises different modes and semiotic resources in order to articulate the meaning in a given realisation. In this case, these were the supratextual vehicles like the structure of the unit flow, the frequency or the order of appearance of the human and generic actors. The polyphony approach discusses, on the level of the context and cotext, the specific positions of different actors in the discourse and their mutual relation. Furthermore, it explains the presupposing dominating position of the discourse (i.e. a specific taboo or nonquestionable value). In this case, we can recognise the constant focus on and emphasis of the actions of a given actor, who stays relevant even in the context of the newsbites with other explicit actors. The represented actors come in various forms (e.g. implicit/explicit, active/passive, objectified/personalised, emphasised/omitted etc.) constituting meaning through the represented action, relation to other actors, expressed or ascribed position and the proportion of the positions in the unit or the flow (Krasni 2017a: 226-229). Proportions concerning the subject position in the discourse depend heavily on the media format and the type of unit. However, when analysing the discursive flow, they reveal the position of the implicit (or infrastructural) actors such as the medium or the agency. The main difference to the previous example lies in the institutionally controlled editing process and the deliberation process in design - or the construction - of the flow. For that reason, the selected generic visual material gains its meaning in the flow through ascribing semiotic values from the context and the cotext. 
Example 3: Portal of a TV Show ${ }^{7}$

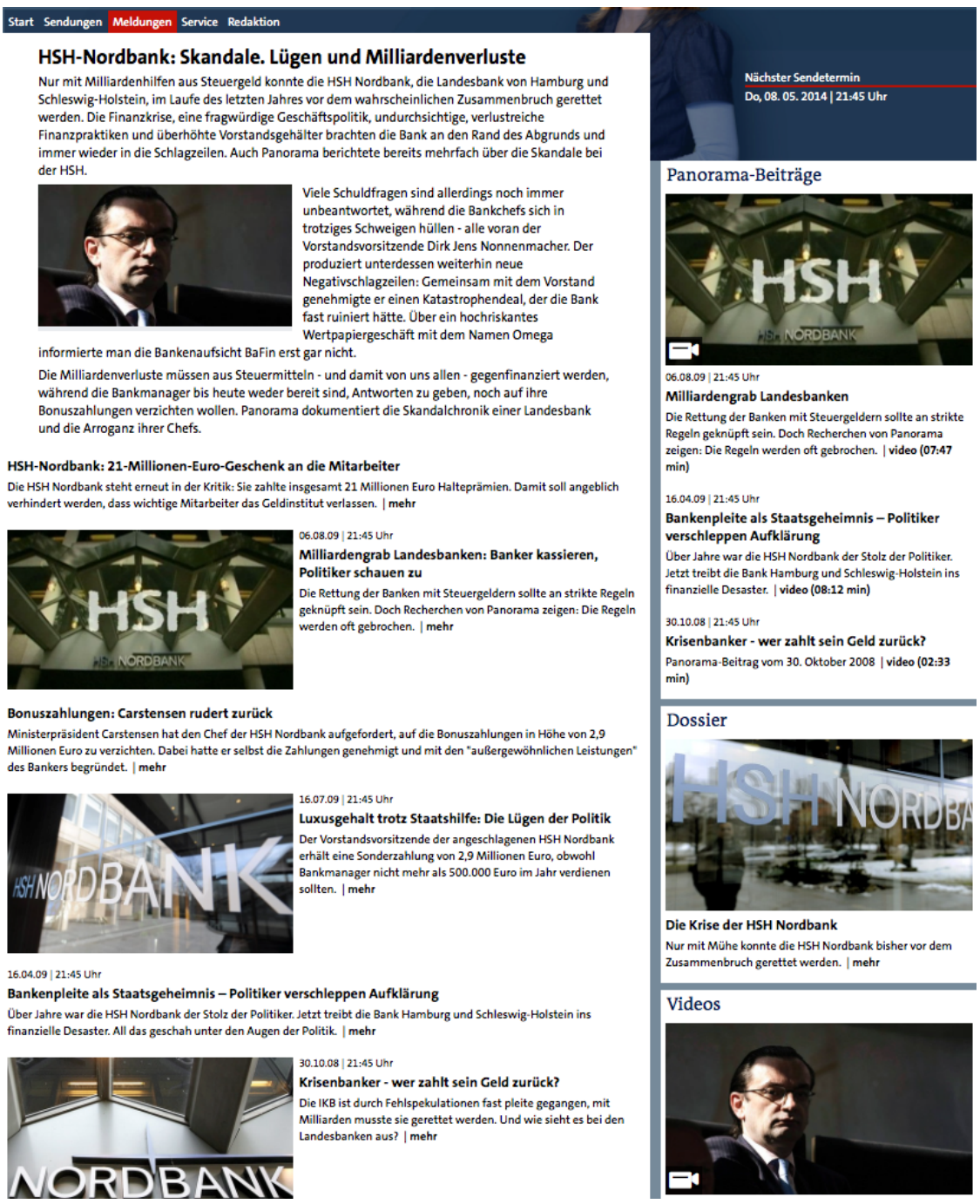

Figure 3: Portal page of the Panorama dedicated to the HSH-Nordbank scandal

${ }^{7}$ This section is closely related to the chapter from my monograph Schuld und Krise (Panorama Portal - Motive als Erinnerungsmuster, 178-200). 
The last example is based on the portal of Panorama TV show from the German public broadcaster ARD. ${ }^{8}$ The show is known for investigative and critical journalism and for its continuous dealing with topics of great social importance. The show was dedicated for several years to the financial crisis in the north of Germany and the situation with the HSH-Bank (tied to the economy of the city of Hamburg and the northern German province of SchleswigHolstein). In the course of the years, the scandal of the government bailout was closely connected with the (mis)management of the bank during the crisis. The new head manager Dirk-Jens Nonnenmacher, selected for the position after the outburst of the crisis, became the main actor of the news related to the bank until 2014. The website of the TV show dedicated many pages to this topic, but a little sub-portal, where some of the shows from the programme's early phase and the especially important excerpts from different shows are linked, serves as an example for the memory construction.

This page can be seen as the online 'place of remembrance'. It represents the mainstream media interpretation - a myth - of the fall of the most important bank from the northern Germany. In spite of that, the reasons, the actors and the consequences of the mismanagement are stated and described in the respective articles, documents and videos reachable from this page. However, in the newsbites, the largest number of the visual representations show the bank and only two of them show the human actor (the manager Nonnenmacher). The name of the bank is repeated 13 times in the textual part of the page and in all the visual representations. Therefore, the bank has a double function in this format - it is both the actor and the topos, the place of the event. The mostly passivized actorship is recognisable from the textual part of different newsbites (the bank being the 'victim' of the mismanagement: "it gives the million bonuses", "it should be saved", "it runs the province in the financial disaster"); its topicality, i.e. the role as a place of an event, is clear from the visual elements. The visual representation of the bank can be seen as rather generic - we see a glass element where only the animated or printed text explains the place. Ascribing the architectural element with a meaning leads to its ambiguous and (partly) personalised role. This element emphasizes the localisation in the 'outside' world (extradiscursive/extradiegetic) and thereby as a mnemotechnic vehicle.

The display of the human actor, on the other side, creates a specific relation - being the only human actor in the context of the page content composition, he gains a specific semiotic value. Based on the contrast between human - nonhuman or actor - topos, a relation is built not unlike the one between the background and the foreground, given and new or the topic and the comment. Such contrast leads to the consequential rapport between the two entities. In other words, the 'active' and 'human' stands for the 'responsible' as opposed to the

${ }^{8}$ HSH-Nordbank: Skandale. Lügen und Milliardenverluste. The snapshot comes from: http://daserste.ndr. de/panorama/aktuell/hsh136.html, retrieved on 18.4.2014. Since 2015, the page was changed several times. 
'non-human', 'passive' (and/or 'damaged'). In addition to that, also colours of the given visual elements are suggesting specific meanings. The dark environment of the sole human actor is also opposed to the architectural elements which are richer in light (but equally generic in the sense of their recontextualization potential). In addition to this relation, well grounded in the Gestalt mechanisms of visual art (Arnheim 1996), the textual part suggests the active role of the human actor only a little bit more explicitly. The paragraph to the right of the picture begins with the observation: "many questions on guilt are still not answered", continuing that all the "chiefs of the bank" are silent - in the first place the depicted "chairman Dirk-Jens Nonnenmacher". The strategic placement of the key terms such as the 'guilt', or the function and the name of the actor are suggesting and supporting the meaning and the role of the active human actor already given in the visual realm. This kind of multimodal montage is important because the guilt or the illegal action are not explicitly ascribed to the person, but rather implicitly given. Similar compositions were visible in all of the linked pages reachable from this portal at the time of retrieval which were not dealing with Nonnenmacher. This kind of representation prevailed at the time of retrieval throughout the internal network of the pages on the Panorama website, even though the accusations against Nonnenmacher were not made fully explicit.

The approximate knowledge is constituted throughout the series of iterations of the same discursive positions within the closed network of Panorama website devoted to the problem of HSH-Nordbank and its manager. The representations of both the human and non-human actors are constant - this is illustrated by the action and the position of the media actor. Thematically, these (series of) representations are mostly homogeneous and the material used belongs to the German public broadcaster ARD. In opposition to the previous examples, the public broadcasting company will rather avoid 'importing' the alien content from commercial media agencies into its network. At the same time, this means that it should have the freedom to articulate its own unbiased representations on the given topics. However, the mechanisms of constructing meaning stay mostly the same as in other, privately owned networks. This instance shows the level of formalisation and the stringency of the multimodal montage and visual expression. The creation of the approximate knowledge is not referencing the other media in terms of content, but rather in terms of the discourse. The combination of generic images and video material as well as strong contextualization via text and the montage on the broader level (of the page and/or the network via linking) are not dependent on the material used nor on the imported standpoints toward a problem in discourse. It is the multimodal discourse which determines the expressive means of broadly accepted representations. The constant iterations show how the prevailing media position becomes established as the discourse immanent rationale - even when the position itself is not explicit. The lack of an explicit position is the most important characteristic of this represen- 
tational strategy since the approximate knowledge covers the accepted (continuum of) values.

\section{Discussion and Conclusion}

Three forms of approximate knowledge can be regarded as recontextualization practices of the field of stock imagery - and multimodal compositions based on it: the creative humorous practice by the users in the form of memes, the application of this imagery in the privately-owned media outlets and the usage of this model in larger media infrastructure with the aim of generating discursive subject positions. The authorship in all three cases is problematic because of the use of ready-made elements: the difference between the professional content and the UGN in this case is based on the unproven fact that some of them are 'regular' users and some of them are 'professionals'. Furthermore, in all three cases, the instances of the infrastructure (e.g. communication infrastructure or prefabricated visual elements) are interfering with the forms of narrative (small units such as meme, newsbite or lead) and with the flow of the discourse. In other words, the approximate knowledge of infrastructure functions - emerging from the practice of using it - is deeply intertwined with the awareness of the content meaning and the text/format structure. For this reason, the actorship - or rather the positioning - of the subjects in the discourse has to be broadened to the media actors since they 'orchestrate' the polyphony of represented positions. It is this polyphony of multimodal elements in the discursive flow construed by the media infrastructure that both defines and approximates the knowledge concerning both the mainstream position regarding a specific topic and the communication standards in the online realm.

This concept of fuzzy epistemology is anchored in the reflection upon the productive and receptive digital media practice. Further analysis should therefore include personal browsing narratives, the commenting sections on meme portals and the phenomenon of the viral spreading of content. Only through such in-depth analysis will we be able to comprehend the approximate knowledge of certain events, values and positions and the phenomenon of their active global support in the online realm. Of course, the three cases of approximate knowledge discussed here do not exceed the scope of its existence. One cannot argue that approximate knowledge is only to be found in online media, but in the context of digital fuzziness it shows its specificities immanent to the online infrastructures. Since it is firmly related to the human representational systems (and semiosis), it certainly belongs also to other realms of discursive action.

\section{Literature}

Agamben, Giorgio (2009): What is an Apparatus? And Other Essays. Stanford: Stanford University Press.

Angermuller, Johannes (2014): Poststructuralist Discourse Analysis. Subjectivity in Enunciative Pragmatics. Basingstoke, Houndmills: Palgrave Macmillan 
Angermüller, Johannes (2007a): „Diskurs als Aussage und Äußerung. Die enunziative Dimension in den Diskurstheorien Michel Foucaults und Jacques Lacans.“ In: Ingo Warnke (Hrsg.): Diskurslinguistik nach Foucault. Theorie und Gegenstände. Berlin, New York: de Gruyter, S. 53-80.

Arnheim, Rudolf (1996 [1972]): Anschauliches Denken. Zur Einheit von Bild und Begriff. Köln: DuMont

Assmann, Alleida (2006): „The Printing Press and the Internet: From A Culture Of Memory To A Culture Of Attention." In: Natascha Gentz und Stefan Kramer (Hrsg.) Globalization, Cultural Identities, and Media Representations. Albany: State of New York Press, S. 11-23.

Baetens, Jan; Surdiacourt, Steven (2011): „How to ,Read' Images with Texts: The Graphic Novel Case." In: Eric Margolis und Luc Pauwels (Hrsg.): The Sage Handbook of Visual Research Methods. London: Sage, S. 590-600

Bernstein, Basil (1990): The Structuring of Pedagogic Discourse. London: Routledge.

Boyd-Barrett, Oliver (2010): ,Assessing the prospects for an Asian re-configuration of the global news order." In: Global Media and Communication 6, S. 346-356.

Delorme, Stéphane and Tessé, Jean-Philippe (2010): Éléments d'autocritique (ou comment j'ai raté la séance d'Avatar) entretien avec Zlavoj Žižek. In: Cahiers du Cinema, nr. 655, April 2010.

Ducrot, Oswald (1984): Le dire et le dit. Paris: Minuit.

Foucault, Michel (1980): "The Confession of the Flesh" (1977), interview. In: Power/Knowledge Selected Interviews and Other Writings 1972-1977 (ed. Colin Gordon), London: Harvester Wheatsheaf. pp. 194-228.

Giesecke, Michael (2002): Von den Mythen der Buchkultur zu den Visionen der Informationsgesellschaft, Frankfurt a. M.: Suhrkamp.

Herman, David (2009): Basic Elements of Narrative. Oxford: WileyBlackwell

Knox, John (2007): „Visual-verbal communication on online newspaper home pages." In: Visual Communication 6, S. 19-53.

Knox, John (2009): „Punctuating the home page: image as language in an online newspaper." In: Discourse \& Communication 3, S. 145-172.

Kramer, Stefan (2004): Vom Eigenen und Fremden: Fernsehen und kulturelles Selbstverständnis in der Volksrepublik China. Bielefeld: transcript.

Kramer, Stefan; Ludes, Peter (2010): Networks of Culture: The World Language of Key Visuals. Berlin: Lit.

Krasni, Jan (2014): ,Re-Bombing in Memento. Traumata of Coventry, Belgrade and Dresden in Multimodal Collective Memory." In: Arianna Maiorani, Christine Christie (Hrsg.): Multimodal Epistemologies. Towards an Integrated Framework, London: Routledge, S. 131-144.

Krasni, Jan (2017a): Schuld und Krise. Bonuszahlungen und Verantwortung in Mediendarstellungen der Finanzkrise. Wiesbaden: Springer Verlag. 
Krasni, Jan (2017b): Soziosemiotik und Diskurspolyphonie. Polyphone Positionierungspraktiken in den multimodalen online-Textformaten. In: Ernest W. B. Hess-Lüttich, Heidrun Kämpers, Martin Reisigl und Ingo Warnke (Eds.) Diskurs-Semiotisch: Aspekte multigormaler Diskurskodierung. De Gruyter Mouton, Berlin/Boeston, pp. 311-338.

Kress, Gunther; van Leeuwen, Theo (2006[1996]): Reading Images: A Grammar of Visual Design. London: RoutledgeKrasni, Jan (2015): Reflecting on a Gap Between Polyphony and Multimodality in Online Media Formats. In: Janina Wildfeuer (Ed.): Building Bridges for Multimodal Research. International Perspectives on Theories and Practices of Multimodal Analysis. Bern: Peter Lang

Ludes, Peter (2001): Multimedia und Multi-Moderne: Schlüsselbilder: Fernsehnachrichten und World Wide Web - Medienzivilisierung in der Europäischen Währungsunion. (mit CD-Rom). Wiesbaden: Westdeutscher Verlag.

Machin, David (2004): „Building the World's Visual Language: The Increasing Global Importance of Image Banks in Corporate Media.” In: Visual Communication 3, S. 316-336.

Machin, David; van Leeuwen, Theo (2007): Global Media Discourse: a Critical Introduction. Routledge, London; New York.

Maingueneau, Dominique (2017): The Heterogeneity of Discourse: Expanding the Field of Discourse Analysis. In: Palgrave Communications 4. July 2017. DOI: $10.1057 /$ palcomms.2017.58

Manovich, Lev (2002): The Language of New Media. Cambridge: MIT Press.

Paech, Joachim (2003): „Überlegungen zum Dispositiv als Theorie medialer Topik“. In: Franz-Josef Albersmeier (Hg.): Texte zur Theorie des Films, Stuttgart: Reclam Verlag, pp. 465-498

Pêcheux, Michel (1982): Language, Semantics, and Ideology. New York: St. Martin's Press.

Ryan, Marie-Laure (2007): „Toward a Definition of Narrative.” In: David Herman (Ed.): The Cambridge Companion to Narrative. Cambridge: Cambridge University Press, S. 22-35.

Schnädelbach, Herbert (2002): Erkenntnistheorie zur Einführung. Hamburg: Junius.

Schleichkorn, Henry (2007): Stock Photography. In: Michael Peres (Ed.): Focal Encyclopedia of Photography. 4th Edition. Burlington-Amsterdam: Elsevier/Focal Press pp.350-353

Shifman, Limor (2014): Memes in Digital Culture. Cambridge: MIT Press

Surdiacourt, Steven (2012): Tying Ends Together: Surface and Storyworld in Comics. In: Comics Forum: https://comicsforum.org/2012/12/27/image-narrative-8-tying-ends-together-surface-and-storyworld-in-comics-by-steven-surdiacourt/. Retrieved on 15.10.2017. 
Thussu, Daya Kishan (2007): Media on the Move: Global Flow and ContraFlow. London: Routledge.

Thussu, Daya Kishan (2003): „Live TV and Bloodless Deaths: War, Infotainment and 24/7 News.” In: Daya Thussu, Dess Freedman (Hrsg.): War and the Media: Reporting Conflict 24/7. London, Thousand Oaks: Sage, S. 117-133.

\section{Метаданные статьи}

Название статьи: Цифровая расплывчатость, или das Ungefäre. Семиотика культурных практик в цифровой области

Aвтор: Ян Красни

Аннотация. Автор статьи размышляет о расплывчатых отношениях между репрезентативными практиками в цифровой области, о значении, которое из них возникает, и об их роли в цифровом дискурсе. Медийные практики, усвоенные пользователями медиапространства, значительно влияют на межличностные онлайн дискурсы. Пользователи, однако, только смутно представляют семиотические системы и культуры, которые они воссоздают. Можно определить различные формы приблизительного знания, когда анализируешь рекуррентные образцы практик в различных контекстах. Они показывают, как порожденные содержательные значения переплетаются с медийным форматом и его дистрибутивной инфраструктурой.

Теоретический концепт приблизительного знания (das Ungefäre) будет приведен на примере трех форматов мультимодального онлайн дискурса. Цифровые приблизительные практики включают в себя отношения между распределяемым медиаконтентом и генерируемым пользователями контентом, которые разделяют те же средства производства, сходные инфраструктуры распространения и эстетические стандарты. Эти отношения представляют базовую нить дискурсивного массового производства смысла в онлайн среде, который основывается на приблизительном знании и расплывчатом дискурсивном производстве пользователями. Это содержание в своем потоке представляет серию действий в рамках дискурса и не может быть проанализировано вне технической инфраструктуры, в которой она нуждается для своего существования.

Ключевые слова: мультимодальный дискурс, онлайн медиа средства, семиотика цифровой области, приблизительное знание, культурные практики.

УДК 003

DOI 10.25205/2307-1737-2018-2-250-270

Контактная информация: Ян Красни, доктор философии, доцент, Университет Ниш (Кирилла и Мефодия, 2, Ниш, 18000, Сербия, jan.krasni@filfak.ni.ac.rs) 